DOI : https://doi.org/ 10.24123/jbt.v5i1.2841

\title{
PERAN TAMPILAN PRODUK, KEAMANAN DAN KEMUDAHAN PADA KEPUTUSAN BERTRANSAKSI MENGGUNAKAN JASA PENGIRIMAN SHOPEE
}

\author{
Septiana Novita Dewi ${ }^{1}$, Aris Tri Haryanto ${ }^{2}$ \\ Sekolah Tinggi Ilmu Ekonomi Adi Unggul Bhirawa Surakarta \\ Email : Septianadewi25@yahoo.co.id ${ }^{1}$, Arisharyanto26@yahoo.co.id ${ }^{2}$
}

\begin{abstract}
This research aimed to test and analyze the role of product display, security and ease of transaction decisions using Shopee's shipping services. This research was conducted in the Surakarta area. The object of this research is consumers who have transacted using the Shopee application. The population in this study were consumers who had shopped using the Shopee application who had made transactions at the end of 2019. The sample determination process was carried out based on consumer experience in using the Shopee application. Furthermore, it was ensured that the consumers who were the samples of this study met the specified criteria and were willing to fill out the questionnaire. If they were not willing and do not meet the criteria, then the consumer was skipped and then researcher looked for other consumers who met the sample criteria. By using this technique, not all populations in this study had the same opportunities as research samples. In this study the sample was 56 respondents. This study resulted in a regression equation, it can be seen that product appearance, security and convenience have a positive effect on the decision to transact using Shopee's shipping services. The results of the t-statistical test show that product appearance, security and convenience partially have a significant effect on the decision to transact using Shopee's delivery service
\end{abstract}

Keywords: Product Display, Security and Ease, Transaction Decision.

\section{Pendahuluan}

Konsumen sebagai pengguna produk tentunya mempunyai hak untuk memilih dan menentukan produk mana yang sesuai dengan kebutuhan dan keingginannya. Salah satunya adalah dalam memilih suatu jenis tampilan produk, adanya berbagai macam tawaran serta inovasi-inovasi produk terbaru yang membuat konsumen lebih selektif dalam menentukan pilihannya. Adanya permasalahan tersebut, maka perusahaan harus memberikan inovasi tampilan produk yang diinginkan oleh konsumen yang secara riil dipengaruhi oleh banyak faktor, dimana faktor-faktor tersebut berbeda antara satu dengan yang lain. Perbedaan ini dipengaruhi oleh faktor individu itu sendiri dan juga oleh faktor lingkungan yang mempengaruhinya perilaku konsumen dalam mengambil keputusan pemilihan terhadap tampilan produk yang ditawarkan. Perkembangan internet pada saat ini terus mengalami inovasi dan pengembangan. Bahkan pengusaha-pengusaha dituntut untuk dapat bersaing dengan adanya perkembangan ttekhnologi tersebut. Era digital saat ini menjadi sesuatu yang wajib dipahami dan diterapkan pada dunia usaha. Semakin 
meningkatnya kemampuan intelektual dan inovasi perkembangan teknologi, akan membentuk fenomena era digital yang lebih canggih. Berbagai sosial media lahir dan bertumbuh subur dan banyak konsumennya. Sosial media telah menjadi bagian dari gaya hidup kekinian. Sosial media dengan berbagai karakter dan keharusan yang perlu dimanfaatkan dalam memberikan informasi-informasi sajian produk agar menjadi sebuah keunggulannya bagi perusahaan dan mampu memberikan daya tarik tersendiri bagi konsumennya.

Tingginya penggunaan internet di Indonesia, dimanfaatkan oleh banyak orang sebagai peluang bisnis yang menjanjikan. Hal ini terlihat dari banyaknya toko online yang bermunculan di media sosial yang diyakini efektif sebagai media mempromosikan tampilan produk (Pramono et al., 2020). Berikut merupakan gambaran proyeksi pengguna internet di Indonesia disajikan pada Gambar 1 di bawah ini:

Gambar 1. Proyeksi Pengguna Internet di Indonesia

Proyeksi pengguna internet di Indonesia periode 2017-2023

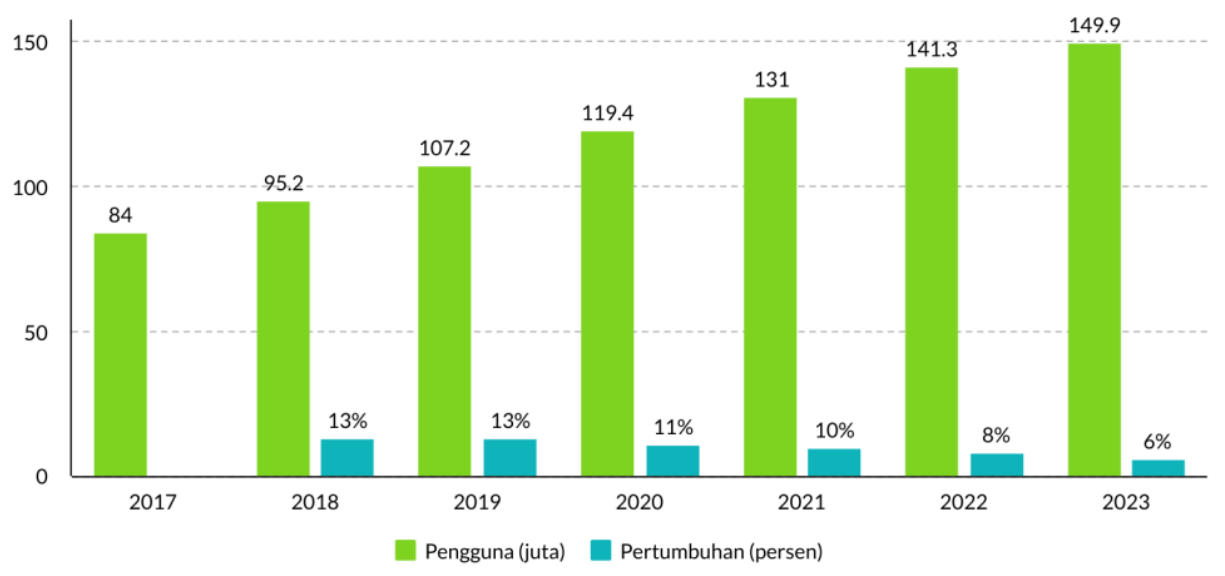

Sumber : Good News From Indonesia, 2020

Gambar 1. di atas menunjukkan bahwa diprediksi Indonesia akan terus mengalami peningkatan jumlah pengguna internet, hal ini perlu disikapi oleh pengusaha untuk tetap bertahan dan mengembangkan bisnisnya dengan selalu mengikuti perkembangan internet dan proses pemasaran produk yang lebih efektif dan efesien. Di era media digital seperti sekarang ini, memiliki bisnis online memang merupakan salah satu hal yang sangat menguntungkan bagi pengusaha maupun konsumen. Setelah masyarakat mengenal sistem transaksi jual beli secara online, maka dewasa ini pun diketahui bahwa tingkat pengguna layanan jual beli online memang semakin meningkat dan beranekaragam. Hal tersebutlah yang membuat segmen bisnis online kini meningkat drastis. Terlebih, saat ini semakin banyak situs jual beli atau marketplace online yang khusus menyediakan transaksi jual beli secara online. Dan sebut saja salah satunya yakni Shopee.co.id ini, aplikasi ini menjadi salah satu aplikasi yang banyak dimanfaatkan oleh masyarakat untuk berbelanja secara online. Namun tentu saja tidak berbeda jauh dengan situs e-commerce lainnya, Shopee juga memiliki sederetan kelebihan dan kekurangan tersendiri dalam menjalankan aplikasinya. Kelebihan menggunakan aplikasi shopee diantaranya adanya kemudahan dalam menginput gambar tampilan produk yang mencapai 9 gambar dapat diupload secara bersamaan di Shopee. Pada bagian penjualan, terdapat fitur yang akan mempermudah penjual ketika menanti pembayaran dan mempunyai informasi yang jelas posisi produk yang telah dipesan, tampilan produk yang 
harus dikirim, hingga status transaksi yang sudah selesai. Adanya fitur khusus "barang diblokir" yang dapat memudahkan pengguna ketika ada masalah pada tampilan produk yang dijual. Fitur varian tampilan produk yang akan mempermudah dan sangat cocok untuk penjualan tampilan produk yang memiliki ragam warna, motif, aatu ukuran. Terdapat fitur untuk mengambil foto dari Instagram dan menambahkan hastag hingga 18 maksimum hastag. Tidak memiliki batasan pada tampilan produk yang akan dijual di aplikasi Shopee. Kekurangan menggunakan aplikasi shopee adalah adanya bagian pembeli dan penjual, sehingga terkesan tidak efisien dan rumit. Untuk promo ongkos kirim gratis, syarat yang harus dipenuhi terkesan sulit dan merepotkan terkadang untuk mengklaim promo gratis ongkir hanya khusus barang-barang tertentu hal ini kadang membuat persepsi konsumen bahwa proses promosi tidak sesuai dengan kenyataan. Tampilan deksripsi tampilan produk yang dinilai kurang menarik perhatian para calon pembeli. (wikipedia.org).

Berdasarkan perkembangan dunia digital di atas, apabila pengusaha yang tidak mempromosikan tampilan produknya melalui internet akan merugi dan tergeser oleh perusahaan lain karena menurutnya melakukan komunikasi pemasaran melalui internet sangatlah efektif dan memberikan informasi yang lebih luas dan jelas. Dalam kegiatan pemasaran melalui media sosial memungkinkan pemasar untuk menerapkan strategi pemasaran interaktif dimana konsumen tidak lagi bertindak sebagai peserta pasif yang hanya menerima iklan sebelum melakukan pembelian, melainkan juga ikut proaktif dan interaktif dalam kegiatan pemasaran (Pramono et al., 2020). Terdapat banyak faktor yang menyebabkan konsumen bersikap proaktif dan interaktif dalam berbelanja online di situs internet, yaitu tampilan produk, biaya yang murah, keamanan, jenis barang yang berkualitas, tampilan produk, fasilitas dan kemudahan transaksi (Khafidatul \& Krishernawan, 2020)

Riset ini menggunakan tampilan produk diprediksi dapat mempengaruhi keputusan bertransaksi menggunakan jasa pengiriman Shopee. Hal ini berdasarkan hasil penelitian yang telah dilakukan oleh (Pramono et al., 2020), Maria dan Wijaya (2017) menunjukkan bahwa tampilan tampilan produk mempunyai pengaruh yang signifikan terhadap keputusan bertransaksi. Penelitian (Japarianto \& Adelia, 2020) menjelaskan tampilan produk berpengaruh tidak relevan terhadap keputusan bertransaki, adanya perbedaan hasil riset ini, maka peneliti akan menganalisis kembali hubungan tampilan produk terhadap keputusan bertransaksi.

\section{Landasan teori}

Faktor yang mempengaruhi keputusan bertransaksi menggunakan jasa pengiriman Shopee adalah tampilan tampilan produk. Pentecost dan Andrews (2019) mengemukakan bahwa tampilan tampilan produk didefinisikan sebagai banyak tidaknya variasi tampilan produk yang ditampilkan memberikan kemudahan bagi pelanggan dalam mencari tampilan produk yang dibutuhkan. (Unju et al., 2020) mengungkapkan display tampilan produk dari perspektif pemasar selalu dikaitkan dengan spesifikasi, fitur, fungsi atau kinerja dari suatu tampilan produk. Tampilan tampilan produk juga berperan sebagai pembeda bagi pelanggan antara tampilan produk perusahaan dengan tampilan produk pesaing dalam suatu industri. Menurut Pratomo (2017) sebuah tampilan tampilan produk yang menarik perhatian disebut sebagai tampilan tampilan produk yang cenderung lebih efektif. Menarik perhatian dapat diartikan dengan komposisi warna yang jelas dan memiliki tingkat kontras yang baik namun masih tetap memperhatikan keindahannya dan tidak sekadar menarik perhatian. Faktor lain yang mempengaruhi keputusan bertransaksi menggunakan jasa pengiriman Shopee adalah keamanan. Lee and Turban (2016) menyatakan, satu hal yang sering kali disebutkan mengapa kecil kemungkinan konsumen 
untuk melakukan pembelian online adalah karena rasa khawatir akan konsekuensi yang akan dihadapinya. Keamanan dalam berbelanja online merujuk pada keamanan secara teknologi seperti program yang menjaga privasi, mekanisme verifikasi, dan enkripsi (Mukherjee and Nath, 2017). Klang (2016) menemukan bahwa meskipun pemasar telah meningkatkan system keamanan dan privasi melalui pengembangan teknologi dan mekanisme tertentu, hal itu tidak mampu unt meningkatkan keyakinan konsumen untuk bertransaksi secara online. Sebaliknya Swaminathan et al. (2019) menunjukkan bahwa dengan dikembangkannya sistem pembayaran tertentu mengakibatkan konsumen tidak terlalu memperhatikan unsur keamanan dalam belanja online. Penelitian Rahayu (2017) menunjukkan bahwa kemudahan berpengaruh positif dan signifikan terhadap keputusan bertransaksi. Hasil penelitian Rafidah (2017) menunjukkan bahwa pengaruh keamanan terhadap keputusan bertransaksi secara online adalah berpengaruh positif dan signifikan sedangkan kemudahan berpengaruh positif namun tidak signifikan terhadap keputusan bertransaksi secara online. Adanya hasil yang tidak konsisten atau reseacrh gap penelitian maka perlu dilakukan penelitian lebih lanjut hal ini bertujuan dapat mengatasi kesenjangan tersebut.

Potensi kejahatan yang biasa terjadi pada transaksi online seperti penipuan, pembajakan kartu kredit (carding), transfer dana ilegal dari rekening tertentu sangatlah besar apabila sistem keamanan infrastruktur ecommerce masih lemah. Oleh karena itu, keamanan infrastruktur e-commerce menjadi kajian penting dan serius bagi ahli komputer dan informatika (Rofiq, 2017). Indonesia menduduki peringkat pertama traffic cyber crime. Sebesar $40 \%$ kejahatan cyber berasal dari Indonesia. Hal ini dikarenakan pemerintah belum memiliki keamanan dan ketahanan cyber sehingga kriminalitas di dunia maya marak terjadi. Cyber crime yang terjadi di Indonesia sangat beragam mulai dari pencurian uang virtual, penyebaran virus, hingga pembobolan data rahasia organisasi (Rimanews, 2017). Hal ini yang kemudian juga menjadi permasalahan bagi para netizen untuk melakukan pembelian secara online karena adanya risiko lebih yang harus siap ditanggung oleh netizen ketika melakukan pembelian secara online, seperti pesanan yang kemungkinan tidak dikirim maupun kejahatan-kejahatan lain yang dapat dilakukan secara online.

Terlepas persepsi tentang keamanan ini cukup beragam bagi konsumen, pemasar online perlu meyakinkan calon konsumennya bahwa transaksi yang mereka lakukan sangat aman. Udo (2016) menemukan bahwa 70 persen dari respondennya pasti akan melakukan transaksi online pada saat mereka merasa terlindungi dari sisi privasi dan keamanan. Temuan ini diperkuat oleh (Maulana \& Suryaningwulan, 2020), Hoffman and Novak (2015), (Hanafi, 2020) Reichheld and Schefter (2015), dan Chung and Shin (2010) yang berpendapat bahwa keamanan bertransaksi dalam sistem belanja online menjadi faktor penting untuk menarik pelanggan, mengingat keamanan sebuah situs ritel yang akan berpengaruh pada kepuasan pelanggan. Kemudahan dalam penggunaan adalah salah satu hal yang menjadi pertimbangan bagi pembeli online. Perceived ease of use didefinisikan Chin dan Todd (2015) merupakan seberapa besar teknologi komputer dirasakan relatif mudah untuk dipahami dan digunakan. Menurut Davis (2019) perceived ease of use didefinisikan sebagai tingkat dimana seseorang meyakini bahwa penggunaan Tekhnologi Informasi merupakan hal yang mudah dan tidak memerlukan usaha keras dari pemakainya. Sehingga kemudahan menjadi prioritas bagi konsumen.

Faktor kemudahan ini terkait dengan bagaimana operasional bertransaksi secara online. Pada saat pertama kali bertransaksi online biasanya calon pembeli akan mengalami kesulitan, karena faktor keamanan dan tidak tahu cara bertransaksi secara online pembeli cenderung mengurungkan niatnya untuk berbelanja online (Harun \& Ayu Salmah, 2020). Kemudahan menjadi suatu daya tarik tersendiri, karena kemudahan itu 
yang membuat konsumen tidak perlu berfikir secara ribet akan tetapi jika sebuah aplikasi memberikan kemudahan yang sangat sederhana akan membuat konsumen tidak takut untuk mencoba apliaksi tersebut. Disisi lain ada juga beberapa calon pembeli yang berinisiatif untuk mencoba karena pembeli telah mendapatkan informasi tentang cara bertransaksi online. Dengan menyediakan layanan dan petunjuk bagaimana cara bertransaksi online, mulai dari cara pembayaran, dan fitur pengisian form pembelian akan mempermudah konsumen untuk berbelanja secara online (Amijaya, 2015).

Fenemona lapangan menunjukkan bahwa adanya peningkatan konsumen dalam menggunakan aplikasi Shopee menjadi hal yang menarik untuk diteliti, sehingga masyarakat atau pebisnis dapat mengetahui apa yang dapat membuat Shopee diminati masyarakat. Selama satu tahun beroperasi, Shopee mengklaim kalau mereka telah melayani transaksi senilai US\$1,8 miliar (sekitar Rp24 triliun) dengan pertumbuhan sekitar 43 persen setiap bulannya. Setiap harinya, Shopee rata-rata melayani lebih dari 250.000 transaksi, dengan sekitar 100.000 di antaranya berasal dari Indonesia. Di tanah air sendiri, mereka telah berhasil menjangkau 515 kota dan menggaet ribuan pengguna aktif. Sejak tanggal 4 Februari 2016 yang lalu, Shopee bekerja sama dengan JNE untuk membuat layanan gratis ongkos kirim ke seluruh wilayah Indonesia. Hal ini jelas menarik minat banyak penjual barang yang sebelumnya berdagang di Instagram atau Facebook untuk bergabung dengan Shopee. Tak berhenti sampai di situ, Shopee juga mendorong masyarakat Indonesia untuk berjualan online lewat inisiatif Kampus Shopee. Dengan program tersebut, mereka berusaha memberikan edukasi agar masyarakat bisa belajar keahlian praktis dalam berjualan online. Berdasarkan fenomena di atas, maka perlu dilakukan penelitian yang berjudul "Peran Tampilan Tampilan Produk, Keamanan Dan Kemudahan Bertransaksi Pada Keputusan Bertransaksi Menggunakan Jasa Pengiriman Shopee”.

\section{Metode}

Penelitian ini dilakukan dengan mengambil lokasi penelitian di wilayah Surakarta. Objek penelitian ini adalah konsumen yang pernah bertransaksi menggunakan aplikasi Shopee. Populasi dalam penelitian ini adalah konsumen yang pernah berbelanja menggunakan aplikasi Shopee yang telah melakukan transaksi di akhir tahun 2019. Konsumen yang dijadikan sampel penelitian ini memenuhi kriteria yang ditentukan dan bersedia mengisi kuesioner. Apabila tidak bersedia dan tidak memenuhi kriteria, maka konsumen tersebut dilewati dan selanjutnya mencari konsumen lain yang memenuhi kriteria sampel. Dengan menggunakan teknik ini maka tidak semua populasi yang ada dalam penelitian ini memiliki peluang yang sama sebagai sampel penelitian. didalam penelitian ini sampelnya adalah 56 responden. Teknik analisis riset ini adalah analisis regresi linier berganda dengan menggunakan angket dalam proses pengambilan datanya dengan ketentuan skala likert dengan penilaian skor 1-5.

Gambar 1. Model Penelitian

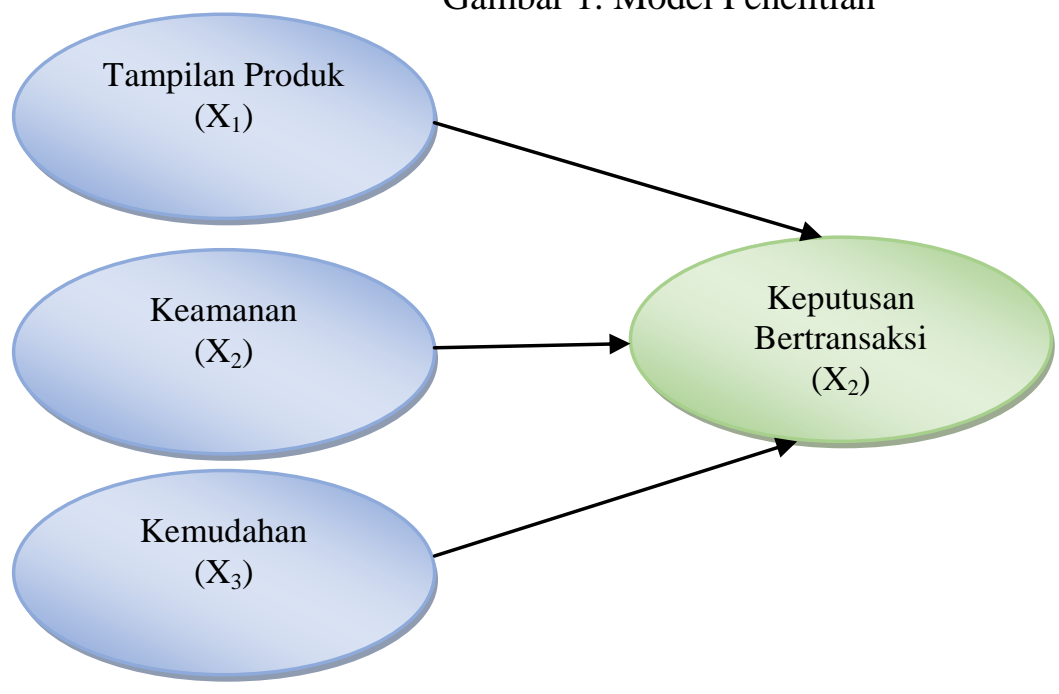




\section{Hasil Penelitian}

Tabel 1. Hasil Uji Validitas Tampilan produk

\begin{tabular}{c|ccc} 
Item Pertanyaan & $\mathbf{r}_{\text {item }}$ & $\mathbf{r}_{\text {tabel }}$ & Ketarangan \\
\hline X1.1 & 0,331 & 0,258 & Valid \\
X1.2 & 0,410 & 0,258 & Valid \\
\hline X1.3 & 0,664 & 0,258 & Valid \\
X1.4 & 0,609 & 0,258 & Valid \\
\hline X1.5 & 0,477 & 0,258 & Valid
\end{tabular}

Sumber: Data diolah, 2020

\begin{tabular}{c|ccc}
$\begin{array}{c}\text { Item } \\
\text { Pertanyaan }\end{array}$ & $\mathbf{r}_{\text {item }}$ & $\mathbf{r}_{\text {tabel }}$ & Ketarangan \\
\hline X2.1 & 0,533 & 0,258 & Valid \\
X2.2 & 0,535 & 0,258 & Valid \\
\hline X2.3 & 0,585 & 0,258 & Valid \\
X2.4 & 0,656 & 0,258 & Valid \\
\hline X2.5 & 0,504 & 0,258 & Valid
\end{tabular}

Sumber: Data diolah, 2020

\begin{tabular}{c|ccc}
\multicolumn{4}{c}{ Tabel 3. Hasil Uji Validitas Kemudahan } \\
Item & $\mathbf{r}_{\text {item }}$ & $\mathbf{r}_{\text {tabel }}$ & Ketarangan \\
Pertanyaan & & 0,258 & Valid \\
X3.1 & 0,434 & 0,258 & Valid \\
X3.2 & 0,590 & 0,258 & Valid \\
\hline X3.3 & 0,668 & 0,258 & Valid \\
X3.4 & 0,708 & 0,258 & Valid
\end{tabular}

Sumber: Data diolah, 2020

Tabel 4. Hasil Uji Validitas Keputusan bertransaksi

\begin{tabular}{c|ccc}
$\begin{array}{c}\text { Item } \\
\text { Pertanyaan }\end{array}$ & $\mathbf{r}_{\text {item }}$ & $\mathbf{r}_{\text {tabel }}$ & Ketarangan \\
\hline Y.1 & 0,291 & 0,258 & Valid \\
Y.2 & 0,562 & 0,258 & Valid \\
\hline Y.3 & 0,676 & 0,258 & Valid \\
Y.4 & 0,627 & 0,258 & Valid \\
\hline Y.5 & 0,462 & 0,258 & Valid
\end{tabular}

Sumber: Data diolah, 2020

\begin{tabular}{|c|c|c|c|}
\hline Variabel & $\begin{array}{l}\text { Alpha } \\
\text { Cronbach }\end{array}$ & Kriteria & Keterangan \\
\hline Tampilan produk & 0,733 & Alpha & Reliabel \\
\hline Keamanan & 0,786 & Cronbach $>0,60$ & Reliabel \\
\hline Kemudahan & 0,800 & maka reliabel & Reliabel \\
\hline Keputusan bertransaksi & 0,750 & & Reliabel \\
\hline
\end{tabular}

Sumber: Data diolah, 2020 


\section{Uji Asumsi Klasik}

1. Uji Normalitas

Gambar.2 Hasil Uji Normalitas

Normal P-P Plot of Regression Standardized Residual

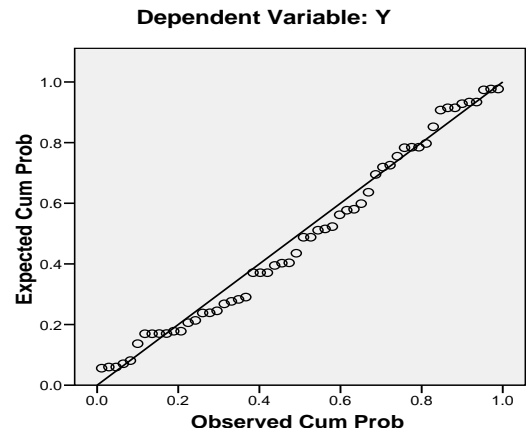

Sumber: Data diolah, 2020

Hasil uji normalitas mengimplikasikan bahwa data terdistribusi secara normal, hal ini berdasarkan grafik probability plot Gambar 2 di atas menunjukkan bahwa titik-titik berhimpit dan melekat serta mengikuti garis diagonal, yang berarti bahwa data terdistribusi secara normal.

2. Uji Heteroskedastisitas

Gambar 3. Hasil Uji Heteroskedastisitas

Scatterplot

Dependent Variable: $Y$

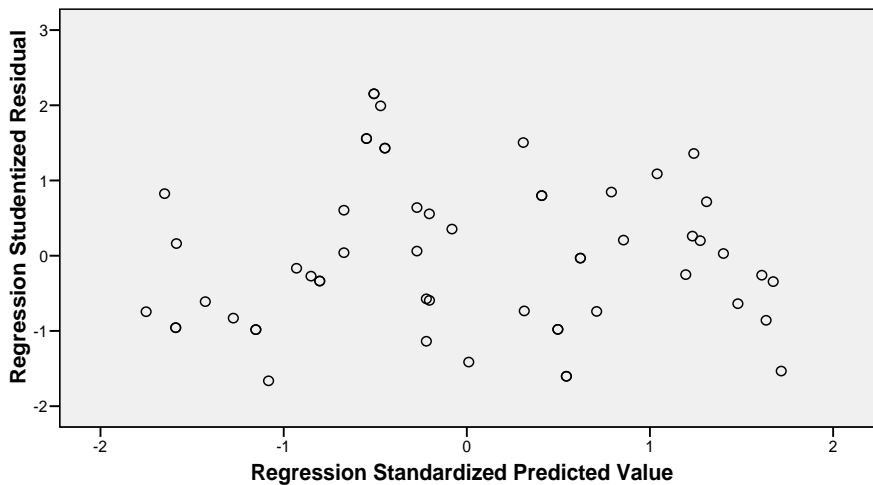

Sumber: Data diolah, 2020

Hasil uji heteroskedastisitas Gambar 3. di atas menunjukkan bahwa tidak ada gangguan heteroskedastisitas, karena berdasarkan grafik Scatterplot di atas titik menyebar secara rata dan tidak membentuk suatu pola tertentu. Sehingga tidak ada gangguan heteroskedastisitas pada riset ini. 
Coefficients

\begin{tabular}{|c|c|c|c|c|c|c|c|c|}
\hline \multirow{2}{*}{\multicolumn{2}{|c|}{ Model }} & \multicolumn{2}{|c|}{$\begin{array}{c}\text { Unstandardized } \\
\text { Coeff icients }\end{array}$} & \multirow{2}{*}{$\begin{array}{l}\text { Standardized } \\
\text { Coeff icients } \\
\text { Beta }\end{array}$} & \multirow[b]{2}{*}{$t$} & \multirow[b]{2}{*}{ Sig. } & \multicolumn{2}{|c|}{ Collinearity Statistics } \\
\hline & & $\mathrm{B}$ & Std. Error & & & & Tolerance & VIF \\
\hline & (Constant) & 3,442 & 1,719 & & 2,002 &, 050 & & \\
\hline & $\mathrm{X} 1$ & ,392 & ,098 & ,389 & 3,996 &, 000 & ,718 & 1,392 \\
\hline & X2 & ,307 & ,082 & ,383 & 3,740 &, 000 & ,648 & 1,544 \\
\hline & $X 3$ & ,191 & ,078 & ,230 & 2,459 & ,017 & ,780 & 1,282 \\
\hline
\end{tabular}

a. Dependent Variable: $Y$

Sumber: Data diolah, 2020

Hasil uji multikolinearitas Tabel 6. di atas dapat diketahui bahwa nilai tolerance $>0,10$ dan nilai $\mathrm{VIF}<10$, sehingga data bebas dari multikolinearitas.

4. Uji Autokorelasi

Tabel 7. Uji Autokorelasi

Model Summary ${ }^{b}$

\begin{tabular}{|l|r|r|r|r|r|}
\hline Model & $\mathrm{R}$ & $\mathrm{R}$ Square & $\begin{array}{c}\text { Adjusted } \\
\text { R Square }\end{array}$ & $\begin{array}{r}\text { Std. Error of } \\
\text { the Estimate }\end{array}$ & $\begin{array}{c}\text { Durbin- } \\
\text { Wat son }\end{array}$ \\
\hline 1 &, $804^{\mathrm{a}}$ &, 646 &, 626 & 1,84468 & 1,893 \\
\hline
\end{tabular}

a. Predictors: (Constant), X3, X1, X2

b. Dependent Variable: $Y$

Sumber: Data diolah, 2020

Uji autokorelasi Tabel 7. Di atas didapatkan nilai Durbin Watson diperoleh nilai sebesar 1,893. Dari hasil tersebut dapat diketahui bahwa nilai Durbin Watson adalah 1,893 terletak antara -3 sampai +3 berarti data tidak terjadi autokorelasi.

\section{Uji Hipotesis}

1. Analisis Regresi Linier Berganda

Tabel 8. Hasil Uji Regreis Linier Berganda Coefficients ${ }^{a}$

\begin{tabular}{|c|c|c|c|c|c|c|c|c|}
\hline \multirow{2}{*}{\multicolumn{2}{|c|}{ Model }} & \multicolumn{2}{|c|}{$\begin{array}{l}\text { Unstandardized } \\
\text { Coeff icients }\end{array}$} & \multirow{2}{*}{$\begin{array}{c}\text { Standardized } \\
\text { Coefficients } \\
\text { Beta }\end{array}$} & \multirow[b]{2}{*}{$t$} & \multirow[b]{2}{*}{ Sig. } & \multicolumn{2}{|c|}{ Collinearity Statistics } \\
\hline & & B & Std. Error & & & & Tolerance & VIF \\
\hline 1 & (Constant) & 3,442 & 1,719 & & 2,002 & ,050 & & \\
\hline & $\mathrm{X} 1$ & ,392 & ,098 & ,389 & 3,996 & ,000 & ,718 & 1,392 \\
\hline & $\mathrm{X} 2$ & ,307 & ,082 & ,383 & 3,740 & ,000 & ,648 & 1,544 \\
\hline & $X 3$ & 191 & ,078 & 230 & 2,459 & ,017 & 780 & 1,282 \\
\hline
\end{tabular}

a. Dependent Variable: $Y$

Sumber: Data diolah, 2020

Hasil olah data di atas diperoleh pengujian yang telah dilakukan didapat persamaan regresi sebagai berikut:

$\mathrm{Y}=3,442+0,392 \mathrm{X}_{1}+0,307 \mathrm{X}_{2}+0,191 \mathrm{X}_{3}$. 
berikut:

Berdasarkan persamaan regresi tersebut maka dapat diinterprestasikan sebagai

a) Nilai konstanta sebesar 3,442, hal ini menunjukkan bahwa apabila variabel tampilan produk, keamanan dan kemudahan tetap maka keputusan bertransaksi menggunakan jasa pengiriman shopee tetap ada

b) Nilai $b_{1}$ adalah 0,392 , hal ini berarti variabel tampilan produk berpengaruh positif terhadap keputusan bertransaksi menggunakan jasa pengiriman shopee. Artinya apabila tampilan produk ditingkatkan, maka keputusan bertransaksi konsumen akan meningkat.

c) Nilai $b_{2}$ adalah 0,307 , hal ini berarti variabel keamanan berpengaruh positif terhadap keputusan bertransaksi menggunakan jasa pengiriman shopee. Hal ini berarti apabila keamanan ditingkatkan (semakin relatif dan mudah dijangkau), maka keputusan bertransaksi konsumen akan meningkat.

d) Nilai $b_{3}$ adalah 0,191 , hal ini berarti variabel kemudahan berpengaruh positif terhadap keputusan bertransaksi menggunakan jasa pengiriman shopee. Hal ini berarti apabila kemudahan ditingkatkan, maka keputusan bertransaksi konsumen juga akan meningkat

2. Uji Statistik t

Berdasarkan hasil uji statistik t pada Tabel 8. di atas dapat diimplementasikan sebagai berikut:

a) Pengaruh Tampilan produk terhadap keputusan bertransaksi menggunakan jasa pengiriman shopee diperoleh nilai signifikansi sebesar $0,000<0,05$, maka $\mathrm{H}_{0}$ ditolak, yang berarti bahwa variabel Tampilan produk berpengaruh positif dan signifikan terhadap keputusan bertransaksi menggunakan jasa pengiriman shopee. (Sehingga Hipotesis 1 Terbukti).

b) Pengaruh Keamanan terhadap keputusan bertransaksi menggunakan jasa pengiriman shopee diperoleh nilai signifikansi sebesar $0,000<0,05$, maka $\mathrm{H}_{0}$ ditolak, yang berarti bahwa variabel keamanan berpengaruh positif dan signifikan terhadap keputusan bertransaksi menggunakan jasa pengiriman shopee. (Sehingga Hipotesis 2 Terbukti).

c) Pengaruh Kemudahan terhadap keputusan bertransaksi menggunakan jasa pengiriman shopee diperoleh nilai signifikansi sebesar $0,017<0,05$, maka $\mathrm{H}_{0}$ ditolak, yang berarti bahwa variabel Kemudahan berpengaruh positif dan signifikan terhadap keputusan bertransaksi menggunakan jasa pengiriman shopee. (Sehingga Hipotesis 2 Terbukti).

3. Uji Statistik F

Tabel 9. Hasil Uji F

ANOVA ${ }^{\text {b }}$

\begin{tabular}{|ll|r|r|r|r|r|}
\hline \multicolumn{1}{|c|}{} & & Sum of & & & & \\
\hline 1 & Squares & df & Mean Square & F & Sig. \\
\hline & Regression & 322,891 & 3 & 107,630 & 31,630 &, $000^{\mathrm{a}}$ \\
& Total & 176,948 & 52 & 3,403 & & \\
& Total & 499,839 & 55 & & & \\
\hline
\end{tabular}

a. Predictors: (Constant), X3, X1, X2

b. Dependent Variable: $Y$

Sumber: Data diolah, 2020

Hasil uji statistik F Tabel 9 di atas diperoleh nilai $F=31.630$ signifikan $0,000<0,05$, hasil tersebut menjelaskan secara bersama-sama variabel tampilan 
produk, keamanan dan kemudahan mempunyai pengaruh yang signifikan terhadap keputusan bertransaksi menggunakan jasa pengiriman shopee.

\section{Pembahasan}

1. Tampilan produk adalah variabel paling dominan dalam mempengaruhi keputusan bertransaksi konsumen karena memiliki nilai koefisien tertinggi dibandingkan pengaruh variabel yang lain. Berdasarkan hasil analisis dapat diketahui bahwa tampilan produk berpengaruh positif dan signifikan terhadap keputusan bertransaksi menggunakan jasa pengiriman shopee. Hal ini mengidentifikasikan bahwa jika tampilan produk ditingkatkan, maka keputusan bertransaksi menggunakan jasa pengiriman shopee juga akan meningkat. Hal yang perlu dilakukan pengusaha dalam mengembangkan bisnisnya adalah dengan cara:

a. Meningkatkan tampilan yang disediakan sesuai dengan keinginan konsumen, misalnya memberikan tampilan yang lebih berwarna, menarik dan mengambil tema yang baru trend serta menggunakan model yang menarik dan dapat memikat konsumen.

b. Meningkatkan kualitas tampilan produk yang baik, misalnya tampilan dalam pemesanan aneka ragam warna atau pilihan yang dapat dengan mudah dipilih.

c. Meningkatkan karakteristik tampilan produk tersendiri dan menjaga kualitas yang diciptakan, misalnya menggunakan icon-icon yang terkarakter yang mencirikan perusahaan dan hal inilah yang membedakan produk satu dengan produk yang lainnya.

Dengan adanya peningkatan faktor tersebut diharapkan keputusan bertransaksi akan meningkat. Hasil riset ini mendukung penelitian yang dilakukan oleh (Pramono et al., 2020), (Japarianto \& Adelia, 2020) dan (Khafidatul \& Krishernawan, 2020) yang menunjukkan tampilan produk berpengaruh signifikan atau relevan terhadap eningkatan keputusan pembelian, khususnya pembelian menggunakan aplikasi Shopee.

2. Keamanan berpengaruh signifikan terhadap keputusan bertransaksi menggunakan jasa pengiriman shopee. Hal ini mengidentifikasikan bahwa konsumen pada Jasa pengiriman shopee membutuhkan keamanan yang sesuai pasaran untuk meningkatkan keputusan bertransaksinya. Hal tersebut tidak dapat dipungkiri dalam pembelajaan online sistem keamaan menjadi salah satu prioritas konsumen agar tidak terjadi penipuan dalam proses jual beli secara online. Upaya untuk peningkatan keamanan dapat dilakukan dengan cara :

a. Meningkatkan kemanana dengan membuat informasi jaminaan keamanan yang diinginkan konsumen

b. Meningkatkan kemanaan dengan menampilakn beberapa review atau ulasan bagi konsumen yang sudah pernah berbelanja secara online dengan perusahaan atau toko tersebut.

c. Meningkatkan kenyamanan dan kemudahaan saat mengirim uang atau proses pembayaran produk.

Dengan adanya upaya peningkatan keamanan tersebut, diharapkan keputusan bertransaksi konsumen akan meningkat secara optimal. Hal ini menjadi dukungan penelitian yang telah dilakukan oleh (Hanafi, 2020), (Khafidatul \& Krishernawan, 2020), (Unju et al., 2020) yang menjelaskan dalam proses jual beli secara online diperlukannya ulasan atau kemanan yang dapat meyakinkan konsumennya.

3. Kemudahan berpengaruh signifikan terhadap keputusan bertransaksi menggunakan jasa pengiriman shopee. Kemudahan menjadi salah satu pilihan konsumen dalam memutuskan pembelian, salah satunya adalah adanya kemudahan proses pengiriman barangm kemudahan dalam memilih produk, kemudahan dalam pembayaran serta kemudahan berkomunikasi. Hal ini mengidentifikasikan bahwa kemudahan yang 
nyaman sangat dibutuhkan oleh konsumen, oleh sebab itu sistem kemudaha perlu ditingkatkan, hal ini dapat dilakukan dengan cara:

a. Meningkatkan rasa nyaman dalam berbelanja, sehingga keputusan bertransaksi yang dihasilkan juga akan lebih baik.

b. Adanya metode atau cara kemudahan berbelanja secara sederhana dan mudah dijangkau

c. Mudah dalam bertransaksi

d. Adanya lingkungan yang mendukung seperti proses pengiriman yag cepat atau kemudahan dalam informasi pengiriman.

Dengan adanya kemudahan yang mendukung proses berbelanja, maka keputusan bertransaksi konsumen di Jasa pengiriman shopee juga akan meningkat secara maksimal. Riset ini sejalan dengan riset yang dilakukan (Harun \& Ayu Salmah, 2020), (Latief \& Dirwan, 2020) yang menjelaskan kemudahan berpengaruh sigifikan terhadap keputusan pembelian.

\section{Simpulan}

1. Penelitian ini menghasilkan persamaan regresi dapat diketahui bahwa tampilan produk, keamanan dan kemudahan berpengaruh positif terhadap keputusan bertransaksi menggunakan jasa pengiriman Shopee.

2. Tampilan produk signifikan terhadap variabel keputusan bertransaksi menggunakan jasa pengiriman Shopee.

3. Keamanan signifikan terhadap variabel keputusan bertransaksi menggunakan jasa pengiriman Shopee.

4. Kemudahan berpengaruh signifikan terhadap variabel keputusan bertransaksi menggunakan jasa pengiriman Shopee.

\section{Saran dan Rekomendasi}

1. Tampilan produk merupakan variabel yang paling dominan maka pihak Shopee perlunya memperhatikan varibel tampilan produk secara maksimal.

2. Penelitian selanjutnya diharapkan menanmbah sampel penelitian atau lingkup yang berbeda dengan produk yang lain.

3. Penelitian yang akan datang diharapkan mengembangkan model penelitian dengan menambah variabel mediasi atau moderasi agar keputusan bertransaksi lebih meningkat lagi.

\section{Daftar Pustaka}

Adityo, Benito. 2016. Analisis Pengaruh Kepercayaan, Kemudahan dan Kualitas Informasi Terhadap Keputusan bertransaksi Secara On Line di Situs Kaskus. Fakultas Ekonomi Universitas Diponegoro: Semarang

Amijaya, GilangRizky. 2015. "Pengaruh Persepsi Teknologi Informasi, Kemudahan, Resiko dan Fitur Layanan Terhadap Minat UlANG Nasabah Bank BCA". Skripsi.Fakultas Ekonomi Universitas Diponegoro. Semarang

Chung, KH., and JI. Shin. 2015. "The antecedents and consequents of relationship quality in internet shopping". Asia Pacific Journal of Marketing and Logistics. 22 (4). 473-91. 
A. Davis, Fred D. 2019). "Perceived Usefulness, Perceived Ease of Use, and User Acceptance of Information Technology". MIS Quarterly Vol 13 (3): 319-340.

Hanafi, I.2020. "Risiko Terhadap Minat Beli Via Media Online". PERFORMA : Jurnal Manajemen Dan Start-Up Bisnis, 4(6), 921-932.

Harun, A., \& Ayu Salmah, N. N. 2020."Pengaruh Kepercayaan dan Kemudahan Terhadap Keputusan Pembelian Online Melalui Aplikasi Shopee". Jurnal Media Wahana Ekonomika, 17(2), 114. https://doi.org/10.31851/jmwe.v17i2.4318

Japarianto, E., \& Adelia, S. 2020. "Pengaruh Tampilan Web Dan Harga Terhadap Minat Beli Dengan Kepercayaan Sebagai Intervening Variable Pada E-Commerce Shopee".Jurnal Manajemen Pemasaran,14(1), 35-43. https://doi.org/10.9744/pemasaran.14.1.35-43

Kotler, Philip dan Kevin L. Keller. 2015. Manajemen Pemasaran (terjemahan :BobSabran, , Edisi 13 jilid 1 dan 2 , penerbit: PT. Index

Khafidatul, \& Krishernawan. (2020)."Maker: Jurnal Manajemen Pengaruh Ulasan Produk, Kemudahan, Kepercayaan, dan Harga Terhadap Marketplace Shopee di Mojekerto". Jurnal Managemen, 6(May), 31-42.

Latief, F., \& Dirwan, D. (2020). "Pengaruh Kemudahan, Promosi, Dan Kemanfaatan Terhadap Keputusan Penggunaan Uang Digital". Jurnal Ilmiah Akuntansi Manajemen, 3(1), 16-30. https://doi.org/10.35326/jiam.v3i1.612

Maria dan Wijaya, (2017). "Analisa Pengaruh Kepercayaan, Kemudahan, Kualitas Informasi dan Tampilan Tampilan produk Terhadap Keputusan bertransaksi Melalui Pemasaran di Media Sosial (Studi Pada pengguna Media Sosial di Shapeharve). Jurnal Manajemen Perhotelan Vol.3 No. 4 2017, Universitas Kristen Petra, Surabaya, Indonesia.

Megawati dan Jasfar, (2014). "Pengaruh Rancangan Situs, Keamanan, Kepercayaan dan Keamanan Terhdapap Pembelian tampilan produk Fashion Melalui Online Shopping". Jurnal Manajemen dan Pemasaran Jasa Volume 7, No.2 Tahun 2014

Mukherjee, A., and P. Nath. 2017. "A model of trust in online relationship banking". International journal of Bank Marketing. 21 (1). 5-15.

Pramono, A., Eldine, A., \& Muniroh, L. (2020)." Pengaruh Harga, Ulasan, Dan Tampilan Produk Terhadap Keputusan Pembelian Secara Online." Manager: Jurnal Ilmu Manajemen, 3(3), 421. https://doi.org/10.32832/manager.v3i3.3909

Rafidah dan Djawoto (2017). "Analisis Keamanan, Kemudahan dan kepercayaan Terhadap keputusan bertransaksi Secara Online di Lazada"". Jurnal Ilmu dan Riset Manajemen Volume 6, Nomor 2, Februari 2017

Rahayu (2017). "Pengaruh Kemudahan, Keprcayaan dan Kualitas Informasi Terhadap keputusan bertransaksi Secara Online di Tokopedia". Jurnal Ilmu dan Riset Manajemen Volume 6, Nomor 10, Oktober 2017 ISSN: 2461-0593

Reichheld, FF., and P. Schefter. 2015. Eloyalty: your secret weapon on the web. Harvard Business Review. July-August. 105-13. 
Rofiq, Ainur. 2017. "Pengaruh Dimensi Kepercayaan (Trust) Terhadap Partisipasi Pelanggan E-Commerce (Studi pada Pelanggan E- Commerce di Indonesia".Tesis.Fakultas Ekonomi Universitas Brawijaya. Malang

Sarwono dan K. Prihartono. 2017. Perdagangan Online: Cara Bisnis di Internet. PT. Elex Media Komputindo. Jakarta

Schiffman, L., Kanuk, L. L. 2018. Perilaku Konsumen, Edisi Ketujuh (EdisiBahasa Indonesia). Jakarta: PT. Indeks

Swaminathan, V., E. Lepkowska-White, and BP. Rao. 2019. "Browser or buyers in cyberspace? An investigationof factors influencing electronic exchange". Journal of Computer-Mediated Communication. 5 (2)

Tustin, D. 2016. "The prevalence of impulsive, compulsive and innovative shopping behaviour in the economic retail hub of south africa: A Marketing Segmentation Approach". African Journal Of Business Management Vol. 5, No. 14, pp:54245434.

Udo, GJ. 2016. "security ecommerce: a survey study. Information" Management \& Computer Security. 9 (4). 165-74.

Wardoyo dan Andini (2017). "Faktor-faktor yang Berpengaruh Terhadap Keputusan bertransaksi secara Online Pada Mahasiswa Universitas Gunadarma". Jurnal Ekonomi Manajemen Sumber Daya Vol. 19, No. 1, Juni 2017 
